\title{
Pengertian dan Perkembangan Antropologi Hukum
}

\author{
Nama Mahasiswa : ABDUL RIVAI \\ Email: Abdulrivai478@gmail.com \\ No BP: 2110003600161 \\ Perguruan Tinggi : Universitas Ekasakti Padang
}

\section{A. PENDAHULUAN}

Antropologi hukum pada dasarnya adalah sub disiplin ilmu hukum empiris yang memusatkan perhatiannya pada studi-studi hukum dengan menggunakan pendekatan antropologis. Kendati demikian, dari sudut pandang antropologi, sub disiplin antropologi budaya yang memfokuskan kajiannya pada fenomena empiris kehidupan hukum dalam masyarakat secara luas dikenal sebagai antropologi hukum. Awal 1970-an dapat dicatat sebagai formulasi dari perkembangan pendidikan ilmu hukum empiris dengan menggunakan pendekatan sosiologis untuk mengkaji fenomenafenomena hukum dalam masyarakat sedang berkembang di Indonesia, yang dikenal kemudian sebagai disiplin sosiologi hukum. Sejak warsa 1980-an dunia pendidikan ilmu hukum di Indonesia semakin diperkaya dengan pengenalan studi-studi hukum empiris dengan menggunakan pendekatan antropologis Antropologi didefinisikan oleh Keesing merupakan suatu ilmu yang mempelajari kajian tentang manusia. Menurut pendapatnya, antropologi terdorong untuk berorientasi pada upaya pemahaman makna bukan hanya sekadar ukuran yaitu dengan lebih menekankan pada penafsiran yang dekat dengan hakikat manusia atau human being (kemanusiaan). Antropologi secara etimologis berasal dari bahasa 
Yunani. Kata Anthropos berarti manusia dan logos berarti pengetahuan. Jadi, antropologi adalah ilmu yang mempelajari tentang manusia. Oleh karena itu, antropologi didasarkan pada kemajuan-kemajuan yang telah dicapai dalam ilmu pengetahuan sebelumnya.

Ernst Utrecht mengutip dari buku Dasar -Dasar Ilmu Hukum (2000) karya Prof. Chainur Arrasjid menyatakan bahwa hukum menurut Ernest Utrecht adalah: "Hukum adalah himpunan petunjuk hidup (perintah atau larangan) yang mengatur tata tertib dalam suatu masyarakat yang seharusnya ditaati oleh anggota masyarakat yang seharusnya ditaati oleh anggota masyarakat dan jika dilanggar dapat menimbulkan tindakan dari pihak pemerintah dari masyarakat itu". sedangkan menurut JTC Simorangkir dan Woerjono Sastropranoto mengarakan bahwa "Hukum adalah peraturan-peraturan bersifat memaksa yang dibuat oleh badanbadan resmi yang berwajib, yang menentukan tingkah laku manusia dalam lingkungan masyarakat, pelanggaran terhadap peraturan tersebut akan berakibat diambilnya tindakan berbentuk hukuman.

Antropologi hukum adalah kajian antropologis terhadap makna sosial dari dan pentingnya hukum dengan menelaah bagaimana hukum dibuat termasuk bagaimana konteks sosial pembuatan hukum tersebut, bagaimana hukum mempertahankan dan mengubah institusi sosial lainnya, dan bagaimana hukum membangun perilaku sosial. Antropologi hukum juga mengkaji peran, status atau kedudukan, nilai, norma, dan budaya. Semua itu merupakan hal-hal yang erat kaitannya dengan 
antropologi hukum. Dengan mempelajari antropologi hukum, dapat melihat bahwa manfaat antropologi hukum dapat dilihat tidak hanya dari segi kebutuhan teoritis, tetapi juga dalam meningkatkan kualitas pemikiran ilmiah, terutama di lingkungan universitas, terutama dalam ilmu-ilmu sosial dan khususnya di antaranya. yaitu kajian ilmu-ilmu sosial serta ilmu-ilmu budaya dan sosial dan hukum, khususnya bagi para praktisi hukum, yaitu dalam rangka pembangunan hukum, pembentukan peraturan perundang-undangan, penegakan dan penerapan hukum dan keadilan dalam kehidupan masyarakat sehari-hari..

\section{B. PEMBAHASAN}

Antropologi hukum adalah kajian antropologis terhadap makna sosial dari dan pentingnya hukum dengan menelaah bagaimana hukum dibuat termasuk bagaimana konteks sosial pembuatan hukum tersebut, bagaimana hukum mempertahankan dan mengubah institusi sosial lainnya, dan bagaimana hukum membangun perilaku sosial. Pemikiran antropologis tentang hukum dimulai dengan kajian-kajian yang dilakukan oleh para antropolog, bukan sarjana hukum. Awal antropologi hukum biasanya dihubungkan dengan karya klasik Sir Henry Maine The Ancient Law, pertama kali diterbitkan pada tahun 1861. Tema kajian pada tahap awal kajian hukum teoretis dengan pendekatan antropologi lebih menitikberatkan pada fenomena hukum pada masyarakat primitif, tradisional dan kesukuan dalam skala evolusi bentuk-bentuk organisasi sosial dan hukum yang memandu perkembangan masyarakat. Terdapat 5 fase tentang Antropologi hukum. 


\section{Fase awal studi teoritis mengenai hukum dengan pendekatan antropologis.}

Pada awalnya, pemikiran antropologis tentang hukum dimulai dengan studi oleh para antropolog dan bukan oleh Sarjana Hukum. Hal ini biasanya dikaitkan dengan awal lahirnya antropologi hukum dengan Hukum Kuno Sir Henry Maine Pertama kali diterbitkan pada tahun 1861. Ia dianggap sebagai landasan studi Anda teori hukum antropologi melalui pengenalan teori evolusionis (the teori) dalam kaitannya dengan masyarakat dan hukum, yang secara singkat menyatakan: Hukum berkembang dengan dan sesuai dengan perkembangan masyarakat masyarakat sederhana (primitif), tradisional dan kesukuan (tribal).masyarakat yang kompleks dan modern serta hukum-hukum yang melekat dalam masyarakat awalnya menekankan status, bentuknya berkembang menjadi bentuk kontrak.

Pokok kajian pada tahap awal ini difokuskan pada fenomena hukum pada masyarakat primitif, tradisional, dan kesukuan dalam skala evolusioner bentukbentuk organisasi sosial dan hukum yang mengiringi perkembangan masyarakat manusia. Sementara itu, metode sudah menjadi kebiasaan. Memahami fenomena hukum dalam masyarakat inilah yang disebut dengan armchair metodologi, suatu metodologi untuk memahami hukum dalam perkembangan masyarakat melalui kajian yang dilakukan di belakang meja, duduk di kursi empuk, di ruangan yang nyaman, melalui pembacaan dan analisis data dokumenter sebanyak-banyaknya. mungkin dari catatan 
perjalanan petualang atau musafir, dari laporan berkala dan dokumen resmi misionaris, pejabat dan tentara pemerintah kolonial dari koloni mereka.

\section{Fase pada abad ke-20.}

Pada fase ini, pengkajian secara ilmiah dengan menggunakan metode ilmiah seperti sekarang belum dilakukan. akan tetapi ini tidka berarti tidak ada upaya melakukan pengkajiann terhadapmhukum yang berlaku pada saat itu. Hukum pada fase ini lebihh banyak berupa keputusan dari raja atau pemguasa yang bertindak dari $\mathrm{p}$ embuat hukum, sekaligus hakim atau pengambilan keputusan terhadap perkara yang diajukan kepadanya. Pada awal abad ke-20, terjadi peralihan dari metode studi hukum yang dipraktikkan pada awalnya dan menemukan jalannya ke dalam perkembangan metode penelitian lapangan dalam yurisprudensi antropologi. Karya Barton yang berjudul The Laws of Ifugao pertama kali diterbitkan di Tahun 1919 merupakan hasil penelitian lapangan intensif di komunitas suku Ifugao di pulau Luzon, Filipina. Kemudian Kejahatan dan Kebiasaan Malinowski di Masyarakat Savage, pertama kali diterbitkan pada tahun 1926, adalah hasil penelitian lapangan yang luas di komunitas Trobrian di Lingkar Pasifik dan sekitarnya, hingga hari ini metode penelitian lapangan adalah norma. Metode khusus antropologi hukum. Pada awal perkembangan antropologi hukum, topik kajian yang dominan berkisar pada pertanyaan: Apa itu hukum? Apakah ada hukum dalam masyarakat yang sederhana, tradisional dan kesukuan?; Bagaimana hukum muncul dan bekerja dalam kehidupan manusia? 


\section{Fase pada decade 1940an sampai dengan 1950-an}

Pada tahun 1940-an-1950-an, subjek kajian antropologi hukum mulai bergeser ke mekanisme penyelesaian sengketa dalam masyarakat sederhana. Karya klasik Llewellyn dan Hoebel yang berjudul The Cheyenne Way (1941), merupakan hasil studi lapangan bersama oleh seorang sarjana hukum dan seorang antropolog dalam komunitas Cheyenne (suku asli Amerika) di Amerika Serikat. Hoebel kemudian menerbitkan The Law of Primitive Man (1954), diikuti oleh karya Gluckman tentang hukum Barotse dan Lozi di Afrika, karya Bohannan tentang hukum rakyat Tiv, karya Gulliver tentang hukum rakyat Arusha dan Ndendeuli, karya hukum Fallers tentang komunitas suku Soga dan Karya Pospisil tentang hukum Kapauku di Papua. F. von Benda-Beckmann (1989) memaparkan tahapan perkembangan topik antropologi hukum hingga mekanisme penyelesaian sengketa.

\section{Fase pada decade tahun 1960 -an}

Pada tahun 1960-an, kajian antropologi lebih banyak memperhatikan fenomena pluralisme hukum atau pluralisme hukum. Topik pluralisme hukum pertama-tama berfokus pada pluralitas prosedur penyelesaian sengketa melalui mekanisme tradisional, kemudian beralih ke mekanisme dan institusi penyelesaian sengketa di bawah hukum negara kolonial dan negara merdeka. Karya-karya Bohannan, Gluckman, dan Gulliver, misalnya, tidak secara sistematis memperhatikan keberadaan mekanisme dan lembaga penyelesaian sengketa di bawah hukum negara kolonial dan negara berkembang. 


\section{Fase pada decade 1970-an}

Sejak tahun 1970-an tema studi-studi antropologi hukum secara sistematis difokuskan pada hubungan antar institusi-institusi penyelesaian sengketa secara tradisional, neo-tradisional, dan menurut institusi hukum negara. Karya Nader dan Todd (1978), misalnya, memfokuskan kajiannya pada prosedur, mekanisme, dan lembaga penyelesaian sengketa dalam masyarakat tradisional dan modern di beberapa negara di dunia melalui Berkeley Village Law Projects dan menjadi karya yang mengungkap tematik. Tren studi dalam antropologi hukum. Publikasi penting lainnya adalah karya van Rouveroy van Nieuwaal tentang mekanisme penyelesaian sengketa antara Togoans di Afrika, kemudian karya-karya F. von Benda-Beckmann (1979) dan K. von Benda-Beckmann (1984), yang memberikan pemahaman penyelesaian sengketa waris. di bawah Minangkabau setelah Pengadilan Negeri dan di Pengadilan Negeri di Sumatera Barat. Tahap selanjutnya kajian pluralisme dalam penyelesaian sengketa ditinggalkan dan mulai fokus pada kajian pluralisme hukum di luar penyelesaian sengketa. Sebagai perkembangan baru, misalnya, karya Sally F. Moore (1978) tentang pluralitas hukum agraria dalam kehidupan suku Kilimanjaro di Afrika dan mekanisme dalam proses produksi pabrik tekstil Amerika yang terkenal harus dicatat dalam mempelajari pluralisme hukum. Belakangan, kajian pluralisme hukum mulai membahas mekanisme jaminan sosial (social security), pasar dan perdagangan, mekanisme irigasi pertanian, kelembagaan koperasi, dan kredit 
di pedesaan di negara berkembang. Studi-studi ini dikembangkan oleh Departemen Hukum Pertanian di Universitas Pertanian Wageningen. Tahap perkembangan topik pluralisme hukum, yang menekankan pada isu-isu penyelesaian sengketa dan non-dispute, interaksi antara hukum tata negara, hukum kerakyatan atau hukum agama, disebut antropologi hukum oleh F. von Benda-Beckmann (1989) Fase pluralisme hukum. Kecenderungan yang berkembang sejak tahun 1970-an adalah penggunaan pendekatan historis dalam kajian antropologi hukum. Studi Moore (1986), Snyder (1981), F. von Benda-Beckmann (1979), K. von Benda-Beckmann (1984), misalnya, secara eksplisit menggunakan kombinasi dimensi sejarah untuk menjelaskan interaksi lembaga hukum negara. dengan hukum Volkes (Hukum Rakyat) dalam kajian pluralisme hukum dalam penyelesaian sengketa

\section{PENUTUP}

Antropologi hukum pada dasarnya adalah sub disiplin ilmu hukum empiris yang memusatkan perhatiannya pada studi-studi hukum dengan menggunakan pendekatan antropologis. Tema kajian pada tahap awal kajian hukum teoretis dengan pendekatan antropologi lebih menitikberatkan pada fenomena hukum pada masyarakat primitif, tradisional dan kesukuan dalam skala evolusi bentuk-bentuk organisasi sosial dan hukum yang memandu perkembangan masyarakat. Pada tahap awal perkembangan antropologi hukum, inilah pandangan dominan yang menyatakan bahwa hukum berkembang sejalan dengan perkembangan kehidupan masyarakat. Saat itu, pada abad ke-20, kajian antropologi hukum masih terbatas pada 
hal-hal sederhana seperti pengenalan hukum. Tahap selanjutnya dalam perkembangan antropologi hukum adalah studi tentang pluralisme atau pluralisme hukum dalam masyarakat. Dan pada fase terakhir kajian antropologi hukum mengalami peningkatan yaitu masuknya kajian antropologi hukum untuk penyelesaian sengketa sosial yang tentunya berdasarkan metode antropologi hukum, baik tradisional, neo-tradisional maupun dengan bantuan hukum tata negara.

\section{DAFTAR PUSTAKA}

Darmini Roza dan Laurensius Arliman S, Peran Pemerintah Daerah Di Dalam Melindungi Hak Anak Di Indonesia,Masalah-

Masalah Hukum, Volume 47, Nomor 1, 2018.https://doi.org/10.14710/mmh.4 7.1.2018.10-21

Laurensius Arliman S, Peranan Metodologi Penelitian Hukum di Dalam Perkembangan

Ilmu Hukum di Indonesia,Soumatera Law Review, Volume 1, Nomor 1, 201. http://doi.org/10.22216/soumlaw.v1i1.3346.

Laurensius Arliman S, Peran Badan Permusyawaratan Desa di Dalam Pembangunan Desa dan Pengawasan Keuangan Desa, Padjadjaran Journal of Law, Volume 4, Nomor 3, 2017. https://doi.org/10.15408/jch.v4i2.3433.

Laurensius Arliman S, Penanaman Modal Asing Di Sumatera Barat Berdasarkan Undang- Undang Nomor 25 Tahun 2007 Tentang Penanaman Modal, Supremasi Hukum, Volume

1,Nomor 1, 2018.http://dx.doi.org/10.36441/hukum.vli01.102.

Laurensius Arliman S, Memperkuat Kearifan Lokal UntukMenangkal Intoleransi

Umat Beragama Di Indonesia,Ensiklopedia of Journal, Volume 1, Nomor 1, 2 018,https://doi.org/10.33559/eoj.v1i1.18.

Laurensius Arliman S, Perkawinan Antar Negara Di Indonesia Berdasarkan Hukum Perdata Internasional, Kertha Patrika,Volume 39, Nomor 3, 2017, https://doi.o rg/10.24843/KP.2017.v39.i03.p03.

Laurensius Arliman S, Partisipasi Masyarakat Di DalamPengelolaan Uang Desa Pa sca Undang-Undang Nomor 6 Tahun 2014 Tentang Desa, Jurnal Arena Hukum, Volume 12, Nomor 2 , 2019,https://doi.org/10.21776/ub.arenahukum.2019.01202.5.

Laurensius Arliman S, Mewujudkan Penegakan Hukum YangBaik Di Negara Huk um Indonesia, Dialogica Jurnalica,Volume 11, Nomor 1, 2019,https://doi.org/ 10.28932/di.v11i1.1831. 
Laurensius Arliman S, Mediasi Melalui Pendekatan Mufakat Sebagai Lembaga Alternatif Penyelesaian Sengketa UntukMendukung Pembangunan Ekonomi Nasional, UIR LawReview, Volume 2, Nomor 2, 2018,https://doi.org/10.2529 9/uirlrev.2018.vol2(02).1587

Laurensius Arliman S, Peranan Filsafat Hukum DalamPerlindungan Hak Anak Ya ng Berkelanjutan SebagaiBagian Dari Hak Asasi Manusia, Doctrinal, Volume 1,Nomor 2, 2016.

Laurensius Arliman S, Ni

Putu

Eka

Dewi, Protection ofChildren and Women's Rights in Indonesia through

International Regulation Ratification, Journal of Innovation, Creativity and Change Volume 15, Nomor 6, 2021.

Laurensius Arliman S, Gagalnya Perlindungan Anak Sebagai Salah Satu Bagian Dari

Hak Asasi Manusia Oleh OrangTua Ditinjau Dari Mazhab Utilitarianisme, Ju rnal Yuridis,Volume 3, Nomor 2, 2016,http://dx.doi.org/10.35586/.v3i2.180.

Laurensius Arliman S, Tantangan Pendidikan Kewarganegaraan Pada Revolusi 4.0, Jurnal Ensiklopedia Sosial Review,Volume 2, Nomor 3, 2020. 